\title{
Biological characteristics and treatment outcomes of metastatic or recurrent neuroendocrine tumors: tumor grade and metastatic site are important for treatment strategy
}

Su-Jung Kim', Jin Won Kim ${ }^{1,2}$, Sae-Won Han ${ }^{1,2}$, Do-Youn Oh ${ }^{1,2 *}$, Se-Hoon Lee ${ }^{1,2}$, Dong-Wan Kim,2, Seock-Ah Im², Tae-You Kim ${ }^{1,2}$, Dae Seog Heo ${ }^{1,2}$, Yung-Jue Bang ${ }^{1,2}$

\begin{abstract}
Background: Studies about the biology, treatment pattern, and treatment outcome of metastatic/recurrent neuroendocrine tumor (NET) have been few.

Methods: We enrolled patients with metastatic/recurrent NET diagnosed between January 1996 and July 2007 and retrospectively analyzed.

Results: A total of 103 patients were evaluated. Twenty-six patients (25.2\%) had pancreatic NET, 27 (26.2\%) had gastrointestinal NET, 2 (1.9\%) had lung NET, 28 (27.2\%) had NET from other sites, and 20 (19.4\%) had NET from unknown origin. The liver was the most common metastatic site (68.9\%). Thirty-four patients had grade 1 disease, 1 (1.0\%) had grade 2 disease, 15 (14.6\%) had grade 3 disease, 9 (8.7\%) had large cell disease, and 7 (6.8\%) had small cell disease.

Sixty-six patients received systemic treatment (interferon, somatostatin analogues or chemotherapy), 64 patients received local treatment (TACE, radiofrequency ablation, metastasectomy, etc.). Thirty-six patients received both systemic and local treatments.

Median overall survival (OS) was 29.0 months (95\% confidence interval, 25.0-33.0) in the103 patients. OS was significantly influenced by grade $(p=.001)$. OS was $43.0,23.0$, and 29.0 months in patients who received local treatment only, systemic treatment only, and both treatments, respectively $(p=.245)$. The median time-to-progression (TTP) was 6.0 months. Overall response rate was $34.0 \%$ and disease-control rate was $64.2 \%$. TTP was influenced by the presence of liver metastasis $(p=.011)$.
\end{abstract}

Conclusions: OS of metastatic/recurrent NET was different according to tumor grade. TTP was different according to metastasis site. Therefore, development of optimal treatment strategy based on the characteristics of NET is warranted.

\section{Background}

In 1890, Ransom described a patient with a carcinoid syndrome and liver metastasis, which was the first report of metastatic neuroendocrine tumor (NET) [1]. Radical surgery has been the only available cure for NETs although more than $50 \%$ of these tumors are

\footnotetext{
* Correspondence: ohdoyoun@snu.ac.kr

'Department of Internal Medicine, Seoul National University Hospital, Seoul

National University College of Medicine, Seoul, Republic of Korea

Full list of author information is available at the end of the article
}

unresectable at diagnosis. And once metastasis presents, NET is usually not curable with their clinical courses being diverse from relatively indolent to aggressive.

In the case of unresectable metastatic NETs, they has been treated with either local treatment modalities or systemic treatment modalities according to location and burden of metastasis or tumor biology [2]. Systemic treatment including interferon (IFN)- $\alpha$, somatostatin analogues, and chemotherapy mainly with streptozotocin has been considered palliative and shown only modest

\section{() Biomed Central}


antitumor activities $[3,4]$. Therefore, local treatment modalities such as palliative surgery, transcatheter arterial chemoembolization (TACE), and radiofrequency ablation (RFA) have been frequently utilized in the metastatic setting, especially for liver metastasis.

Because metastatic/recurrent NET is a rare disease, randomized controlled trials have been lacking. However, incidence of NET is increasing according to the recent US Surveillance, Epidemiology, and End Results (SEER) report which is the largest population-based study to date [5]. Recently with an increased understanding of the biology of NETs, it has been possible to actively investigate novel agents and treatments including targeted therapy with some of them proven to be effective [6,7].

Many studies for malignant NETs were done mainly in Western countries while only few have been done in Asian countries. Besides, studies about the biology, treatment pattern, and treatment outcome of metastatic/ recurrent NET have been few and far between other than early-stage NET. Therefore we conducted this study to reveal the biologic characteristics and treatment outcomes of metastatic/recurrent NET in a referral center in an Asian country.

\section{Methods}

We consecutively enrolled patients with histologically confirmed metastatic/recurrent NET between January 1996 and July 2007 at Seoul National University Hospital. Medullary carcinoma of thyroid, pheochromocytoma, paraganglioma, small-cell and large-cell neuroendocrine carcinoma of the lung, and adrenal cortical carcinoma were excluded in this analysis because those have unique characteristics. We retrospectively analyzed the characteristics of these population, treatment pattern, and treatment outcomes.

Data about stage before progression to metastatic disease or recurrence was obtained. A localized NET was defined as an invasive neoplasm confined entirely to the organ of origin. A regional NET was defined as a neoplasm that extended beyond the limits of the organ of origin directly into surrounding organs or tissue or a neoplasm involving regional lymph nodes. Finally, a metastatic NET was defined as a neoplasm that spread to parts of the body remote from the primary tumor [5].

There has been no established uniform grading system for NETs. We classified "carcinoid tumors" or "islet cell tumors" or well differentiated tumors into grade 1, atypical carcinoid or moderately differentiated tumors into grade 2 , poorly differentiated tumors into grade 3 , and anaplastic tumors into grade 4 according to the SEER [5]. In addition, there were large-cell and small-cell neuroendocrine carcinomas from sites other than the lung and from unknown primary origin. These were also included in our analysis.

To evaluate response to systemic treatment, RECIST (response evaluation criteria in solid tumors) criteria were applied. Statistical analyses were performed using the chi-square and the Fisher's exact test to compare response of systemic treatment. The Kaplan-Meier method was used to estimate overall survival (OS) and the time-to-progression (TTP) after systemic treatment. In multivariate analyses for survival, Cox regression analysis was used. Statistical significance was achieved if the probability was less than $5 \%(p<.05)$. We received approval for this study from the Institutional Review Board of Seoul National University Hospital (IRB No. H-0809-039-256).

\section{Results}

(1) Baseline characteristics

Table 1 includes the baseline characteristics for the whole population. A total of 103 patients were enrolled. The median duration of follow-up was 40.0 months (range, 0.0-159.0). The median age was 54 years (range, 22-78). There were 58 (56.3\%) males.

Twenty-six patients (25.2\%) were diagnosed with pancreatic NET, 27 patients (26.2\%) with GI NET, and 2 patients $(1.9 \%)$ with lung NET. Tumors that originated from sites other than the pancreas, GI tract, and lung were observed in 28 patients (27.2\%). There were 20 patients $(19.4 \%)$ of whom the origin of the tumor was unknown. In GI NET, 11 cases (40.7\%) were foregut NET, 1 case $(3.7 \%)$ was midgut NET, and 15 cases (55.6\%) were hindgut NET. As an initial site of metastasis, the liver was the most common site (50 patients, $74.6 \%)$. As a site of recurrence, the liver was also the most common site $(16,44.4 \%)$.

Sixty-seven patients were diagnosed with metastatic disease from their initial diagnosis, 30 patients had recurrent disease after curative resection and 6 patients had disease which progressed to metastatic disease from a non-metastatic disease state after initial diagnosis.

Regarding the grade classification of NET, 34 patients (33.0\%) had grade 1 disease, 1 patient (1.0\%) had grade 2 disease, 15 patients $(14.6 \%)$ had grade 3 disease, 9 patients had $(8.7 \%)$ large cell disease, and 7 patients (6.8\%) had small cell disease. Grade was unclassified in 25 patients $(24.3 \%)$ and information about grade was unavailable in 12 patients $(11.7 \%)$.

At the time of diagnosis of metastatic/recurrent disease, the median value of 5-hydroxyindoleacetic acid (5HIAA) from 24-hour urine samples was $23.0 \mu \mathrm{mol} /$ day (range, 2.6-1324.6) and the median value of serum levels for neuron-specific enolase (NSE) was $1.6 \mathrm{nmol} / \mathrm{l}$ (range, $0.4-23.1)$ 
Table 1 Baseline characteristics of 103 patients

\begin{tabular}{|c|c|c|c|c|}
\hline \multicolumn{3}{|l|}{ Characteristic } & \multicolumn{2}{|l|}{ Frequency } \\
\hline & Median (years) & & 54 (ran & \\
\hline \multirow[t]{2}{*}{ Age } & $<60$ & & 63 & 61.2 \\
\hline & $\geq 60$ & & 40 & 38.8 \\
\hline \multirow{3}{*}{ Sex } & Male & & 58 & 56.3 \\
\hline & Female & & 45 & 43.7 \\
\hline & Absent & & 92 & 89.3 \\
\hline \multirow[t]{6}{*}{ Carcinoid symptom } & Present & & 5 & 4.9 \\
\hline & Unavailable & & 6 & 5.8 \\
\hline & Pancreas & & 26 & 25.2 \\
\hline & Gl tract & & 27 & 26.2 \\
\hline & Foregut & & 11 & 10.7 \\
\hline & Midgut & & 1 & 1.0 \\
\hline \multirow[t]{4}{*}{ Origin } & Hindgut & & 15 & 14.6 \\
\hline & Lung & & 2 & 1.9 \\
\hline & Etc.* & & 28 & 27.2 \\
\hline & Unknown & & 20 & 19.4 \\
\hline \multirow[t]{6}{*}{ Initial metastatic site } & Liver & & 50 & 74.6 \\
\hline & Bone & & 12 & 17.9 \\
\hline & Lung & & 12 & 17.9 \\
\hline & Brain & & 3 & 4.5 \\
\hline & Lymph node & & 20 & 29.9 \\
\hline & Etc. & & 10 & 14.9 \\
\hline \multirow[t]{7}{*}{ Recurrent site } & Liver & & 15 & 41.7 \\
\hline & Bone & & 16 & 44.4 \\
\hline & Lung & & 1 & 2.8 \\
\hline & Brain & & 1 & 2.8 \\
\hline & Lymph node & & 15 & 41.7 \\
\hline & Etc. & & 3 & 8.3 \\
\hline & Local & & 21 & 21.4 \\
\hline \multirow[t]{4}{*}{ Prior stage } & Regional & & 15 & 14.6 \\
\hline & Distant & & 67 & 65.0 \\
\hline & 1 & & 34 & 33.0 \\
\hline & 2 & & 1 & 1.0 \\
\hline \multirow[t]{7}{*}{ Grade } & 3 & & 15 & 14.6 \\
\hline & Large & & 9 & 8.7 \\
\hline & Small & & 7 & 6.8 \\
\hline & Unclassified & & 25 & 24.3 \\
\hline & Unavailable & & 12 & 11.7 \\
\hline & & Median (range) & $23.0(2$ & \\
\hline & 24-hour urine 5 -HIAA $(\mu \mathrm{mol} / \mathrm{day})^{\dagger}$ & <31.4 (reference range) & 15 & 71.4 \\
\hline \multirow[t]{4}{*}{ Biomarkers } & & $\geq 31.4$ & 6 & 28.6 \\
\hline & & Median (range) & $1.6(C$ & \\
\hline & Serum NSE $(\mathrm{nmol} / /)^{\ddagger}$ & $<1.0$ (reference range) & 12 & 36.4 \\
\hline & & $\geq 1.0$ & 21 & 63.6 \\
\hline
\end{tabular}

Gl, gastrointestinal; 5-HIAA, 5-hydroxyindoleacetic acid; NSE, neuron-specific enolase

* The biliary tract (5 cases), thymus (4), uterus (4), mediastinum (3), oral cavity (2), skin (2), trachea (1), liver (1), kidney (1), pelvis (1), prostate (1), bladder (1), nasal cavity (1), and orbit (1)

† Available data: 21

* Available data: 33 


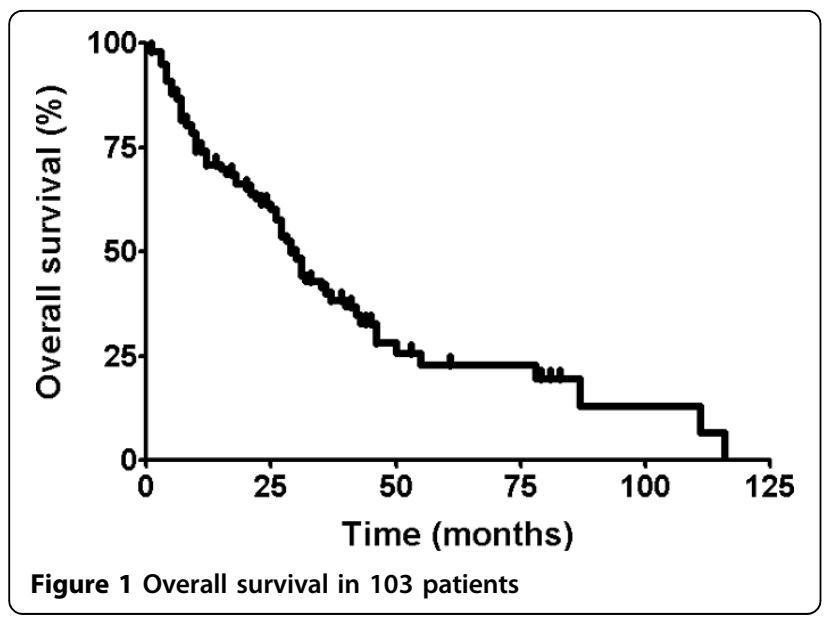

(2) Treatment outcomes and prognostic factors of metastatic/recurrent NET

Figure 1 shows OS in all of the 103 patients. Median OS was 29.0 months (95\% confidence interval [CI], 25.033.0). The three-year survival rate was $39.2 \%$. Table 2 shows OS according to characteristics. Survival was not

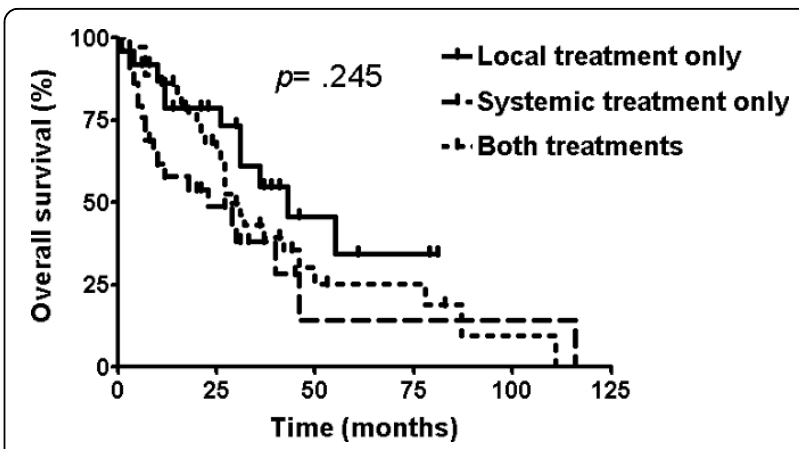

Figure 2 Overall survival by treatment modality

significantly different by age $(p=.053)$, sex $(p=.461)$, carcinoid symptom $(p=.646)$, primary tumor origin $(p=.660)$, presence of liver metastasis $(p=.995)$, elevation of biomarkers $(p=.653$ for urine 5-HIAA; $p=.051$ for serum NSE), and treatment modality (local treatment only vs. systemic treatment only vs. both treatments, $p=.245$ ). Figure 2 illustrates OS according to treatment modality.

Table 2 Overall survival according to characteristics $(n=103)$

\begin{tabular}{|c|c|c|c|c|c|c|}
\hline Characteristic & & & Median OS & $95 \% \mathrm{Cl}$ & $\begin{array}{l}\text { 3-year } \\
\text { survival } \\
\text { rate (\%) }\end{array}$ & $P$-value \\
\hline \multirow{2}{*}{ Age } & $<60$ & & 32.0 & $20.9-43.1$ & 44.2 & \multirow{2}{*}{.053} \\
\hline & $\geq 60$ & & 27.0 & $12.6-41.4$ & 31.0 & \\
\hline \multirow{2}{*}{ Sex } & Male & & 29.0 & $20.5-37.5$ & 36.4 & \multirow{2}{*}{.461} \\
\hline & Female & & 31.0 & $26.7-35.3$ & 42.9 & \\
\hline \multirow{2}{*}{ Carcinoid symptom } & Absent & & 29.0 & $23.3-34.7$ & 40.5 & \multirow{2}{*}{.646} \\
\hline & & & & $23.7-32.3$ & - & \\
\hline \multirow{3}{*}{ Origin } & Pancreas & & 43.0 & $23.4-62.6$ & 45.3 & \multirow{3}{*}{.660} \\
\hline & $\mathrm{Gl}$ & & 40.0 & $10.3-69.7$ & 51.2 & \\
\hline & Lung & & 10.0 & - & - & \\
\hline \multirow{2}{*}{ Liver metastasis } & Absent & & 29.0 & $18.6-39.4$ & 42.2 & \multirow{2}{*}{.995} \\
\hline & Present & & 29.0 & $22.8-35.2$ & 38.1 & \\
\hline \multirow{4}{*}{ Grade } & 1 & & 78.0 & $32.3-123.7$ & 65.8 & \multirow{4}{*}{.001} \\
\hline & $2-3$ & & 18.0 & $1.9-34.1$ & 29.8 & \\
\hline & Large & & 15.0 & $2.8-27.2$ & 13.9 & \\
\hline & Small & & 18.0 & $7.1-28.9$ & 17.9 & \\
\hline \multirow{5}{*}{ Biomarkers } & 24-hour urine 5 -HIAA ( $\mu \mathrm{mol} /$ day) & $<31.4$ & 31.0 & $24.3-37.7$ & 42.8 & \multirow[t]{2}{*}{.653} \\
\hline & & $\geq 31.4$ & 46.0 & - & 66,7 & \\
\hline & & & & & & \\
\hline & Serum NSE (nmol/l) & $<1.0$ & 31.0 & - & 47.7 & .051 \\
\hline & & $\geq 1.0$ & 7.0 & $4.3-9.7$ & 26.8 & \\
\hline \multirow{3}{*}{ Treatment modality } & Local treatment only & & 43.0 & $23.1-62.9$ & 53.0 & \multirow{3}{*}{.245} \\
\hline & Systemic treatment only & & 23.0 & $0.4-45.6$ & 38.0 & \\
\hline & Both treatments & & 29.0 & 23.6-34.4 & 43.0 & \\
\hline
\end{tabular}

OS, overall survival; $\mathrm{Cl}$, confidence interval; Gl, gastrointestinal; 5-HIAA, 5-hydroxyindoleacetic acid; NSE, neuron-specific enolase 


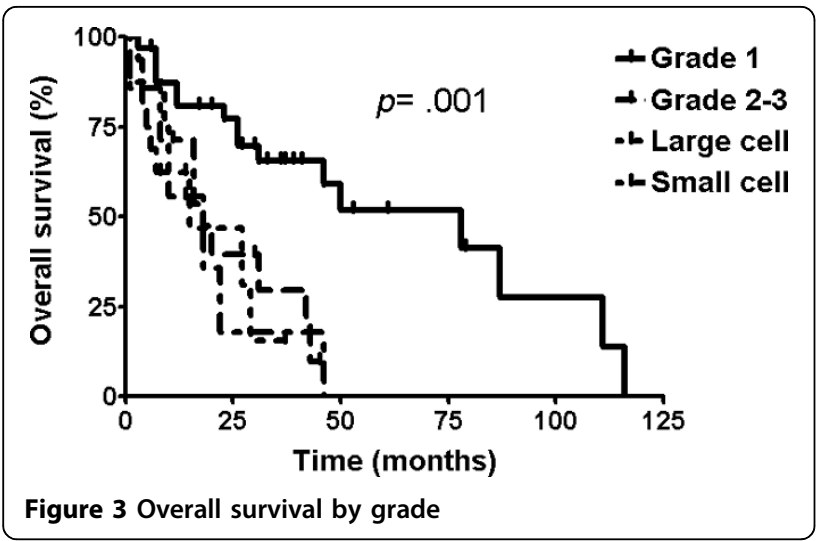

OS was significantly influenced by grade $(p=.001)$ (Figure 3). The significance was derived from the difference between grade $1 \mathrm{NET}$ and the others (grade $2 / 3$, large-cell, and small-cell disease) (78.0 months vs. 18.0 months, respectively).

\section{(3) Patterns of treatment}

As an initial treatment of metastatic/recurrent disease setting, systemic treatment was the most common (43 patients, $41.7 \%)$, followed by TACE $(21,20.4 \%)$, surgery $(13,12.6 \%)$, best supportive care $(10,9.7 \%)$, endoscopic removal $(6,5.8 \%)$, and radiotherapy $(4,3.9 \%)$.

In the entire course of the disease, 66 patients received systemic treatment (IFN, somatostatin analogues, and chemotherapy), 64 patients received local treatment to the metastatic/recurrent site (TACE, RFA, metastasectomy, endoscopic removal, and radiotherapy). Thirty-six patients received both of systemic and local treatment and 9 patients received best supportive care only.

\section{A. Systemic treatment in metastatic/recurrent NET}

Among the 103 patients, 66 patients received palliative systemic treatment. Median time from diagnosis of metastatic/recurrent NET to initiation of systemic treatment was 0.0 months (range, 0.0-77.0). The median line of systemic treatment which was administered was the 2 lines (range, 1st-7th). Among 66 patients receiving the 1 st-line systemic treatment, 36 patients received 2ndline systemic treatment, and among them, 22 patients received 3rd-line systemic treatment. Baseline characteristics among the 66 patients who received palliative systemic treatment are demonstrated in Table 3.

Median OS for the 66 patients was 25.0 months (95\% CI, 18.6-31.4). The three-year survival rate was $32.6 \%$. As a 1st-line systemic treatment, IFN was administered to 15 patients $(22.7 \%)$, somatostatin-analogue to 2 patients (3.0\%), and chemotherapeutic agent to 49 patients $(74.2 \%)$. Drugs which were administered are shown in Table 4.
The median TTP after 1st-line systemic treatment was 6.0 months (95\% CI, 3.3-8.7). One-year progression-free rate was $30.2 \%$ (Figure 4). Overall response rate (ORR) was $34.0 \%$ (CR, 3.8\%; PR, 30.2\%; 95\% CI, 20.8-47.1) and disease-control rate (DCR) was $64.2 \%(95 \% \mathrm{CI}, 50.8$ 77.5) in the 1st-line systemic treatment.

As a 2nd-line systemic treatment, 2 patients (5.6\%) received somatostatin-analogues and 34 patients (94.4\%) received chemotherapy. The median TTP after 2nd-line systemic treatment was 5.0 months (95\% CI, 3.5-6.5). One-year progression-free rate was $14.1 \%$. ORR was $21.4 \%$ and DCR was $53.6 \%$.

As a 3rd-line systemic treatment, 1 patient (4.5\%) received IFN and 21 patients (95.5\%) received chemotherapeutic agents. The median TTP was 2.0 months (95\% CI, 1.5-2.5). One-year progression-free rate was $5.5 \%$. ORR was $12.5 \%$ and DCR was $31.3 \%$.

Tables 5 and 6 show OS, TTP, ORR, and DCR according to the characteristics of the 66 patients. Although OS was not significantly different according to treatment modality $(p=.350)$, OS in patients who received only systemic treatment and not local treatment (23.0 months) seemed to be shorter than the patients who received both local and systemic treatment (29.0 months). OS was different between grade 1 (36.0 months) and the others (17.0 months), although insignificant $(p=.215)$.

TTP was influenced by the presence of liver metastasis $(p=.011)$. The median TTP in the group without liver metastasis was 12.0 months and in the group with liver metastasis was 4.0 months (Figure 5).

There was a relationship between ORR and the presence of liver metastasis $(p=.009)$ or the elevation of serum NSE $(p=.034)$. DCR was not significantly related to any clinical factors.

\section{B. Local treatment in metastatic/recurrent NET}

Twenty-five patients received TACE. Median number of TACE was 4 times (range 1-16). Median time interval of TACE was 3.0 months (range, 0.0-72.0). Six patients received RFA. Median number of RFA was 1 time (range 1-2). Metastasectomy was done to 6 patients. Radiotherapy was given to 15 patients except for palliative radiotherapy of bone metastasis. Five patients had their tumors endoscopically removed.

\section{Discussion}

This study presented the characteristics and treatment outcomes of metastatic/recurrent NET. In our study, the origins of metastatic/recurrent NET was found in diverse places in the body and grade 1 disease was the most common (33.0\%). Median OS was 29.0 months in all of the 103 cases. Median OS for 66 patients who received palliative systemic treatment was 25.0 months. 
Table 3 Baseline characteristics among the 66 patients who received palliative systemic treatment

\begin{tabular}{|c|c|c|c|c|}
\hline \multicolumn{3}{|l|}{ Characteristic } & Frequency & \multirow[t]{2}{*}{$\%$} \\
\hline & Median (years) & & $54(\mathrm{ra}$ & \\
\hline \multirow[t]{2}{*}{ Age } & $<60$ & & 42 & 63.6 \\
\hline & $\geq 60$ & & 24 & 36.4 \\
\hline \multirow[t]{3}{*}{ Sex } & Male & & 41 & 62.1 \\
\hline & Female & & 25 & 37.9 \\
\hline & Absent & & 61 & 92.4 \\
\hline \multirow[t]{4}{*}{ Carcinoid symptom } & Present & & 3 & 4.5 \\
\hline & Unavailable & & 2 & 3.0 \\
\hline & Pancreas & & 2 & 3.0 \\
\hline & $\mathrm{Gl}$ & & 15 & 22.7 \\
\hline \multirow[t]{4}{*}{ Origin } & Lung & & 15 & 22.7 \\
\hline & Etc.* & & 22 & 33.3 \\
\hline & Unknown & & 12 & 18.2 \\
\hline & Local & & 10 & 15.2 \\
\hline \multirow[t]{2}{*}{ Prior stage } & Regional & & 9 & 13.6 \\
\hline & Distant & & 47 & 71.2 \\
\hline \multirow[t]{9}{*}{ Grade } & 1 & & 20 & 30.3 \\
\hline & 2 & & 1 & 1.5 \\
\hline & 3 & & 10 & 15.2 \\
\hline & Large & & 8 & 12.1 \\
\hline & Small & & 5 & 7.6 \\
\hline & Unclassified & & 15 & 22.7 \\
\hline & Unavailable & & 7 & 10.6 \\
\hline & 24-hour urine 5-HIAA $(\mu \mathrm{mol} / \text { day })^{\dagger}$ & Median (range) & 33.5 & \\
\hline & & $<31.4$ & 5 & $45.5 \%$ \\
\hline \multirow[t]{4}{*}{ Biomarkers } & & $\geq 31.4$ & 6 & $54.5 \%$ \\
\hline & & Median (range) & 1.36 & \\
\hline & Serum NSE $(\mathrm{nmol} / \mathrm{l})^{\ddagger}$ & $<1.0$ & 8 & $36.4 \%$ \\
\hline & & $\geq 1.0$ & 14 & $63.6 \%$ \\
\hline
\end{tabular}

Abbreviations as in table 1, 2

*The uterus (4 cases), biliary tract (3), thymus (3), mediastinum (2), oral cavity (2), skin (2), trachea (1), kidney (1), prostate (1), bladder (1), nasal cavity (1), and orbit (1)

+ Available data: 11

₹ Available data: 22

These were comparable to outcome of the SEER analysis which reported an OS of 25.0 months for metastatic NET among Asians and Pacific islanders. The median TTP after 1st-line systemic treatment was 6.0 months with various regimens. Overall response rate (ORR) was $34.0 \%$ and disease-control rate (DCR) was $64.2 \%$ in the 1st-line systemic treatment.

The grade has been known to be prognostic in several studies $[5,8,9]$. OS was significantly influenced by the grade in our study $(p=.001)$. Grade 1 tumors showed longer OS than the others. On the contrary, higher grade predicted better response after systemic chemotherapy in several studies $[2,10]$, while not in others [11].

There are a few reports that revealed the similarity of the natural course and treatment outcome between small cell and poorly differentiated neuroendocrine carcinoma [12], or between high-grade non-small cell neuroendocrine carcinoma of lung and small-cell lung cancer [13]. In our study also, grade-3, large cell, and small cell NET did not show any difference in OS.

There has been no established uniform grading system for NETs. Recently WHO (World Health Organization) or ENET (European Neuroendocrine Tumor Society) grading systems are available. WHO suggested a grading system for gastoenteropancreatic NETs. However, the grading system is not compatible with grading system in lung NETs (typical carcinoid, atypical carcinoid, large cell neuroendocrine carcinoma, and small cell lung cancer). ENETS proposed grading systems for foregut, midgut and hindgut NETs those are composed of mitotic count and Ki-67 index. Because our data dealt with 
Table 4 Drugs which were used in the 1st line

\begin{tabular}{lc}
\hline Drugs & Number \\
\hline Interferon & 15 \\
Somatostatin-analogues & 2 \\
EP, EC & 16 \\
CAV & 3 \\
TC, TP, DP, DC & 4 \\
VIP & 6 \\
Adriamycin+streptozotocin & 2 \\
FOLFOX, XELOX & 2 \\
FP, FC & 4 \\
IP & 1 \\
5-FU+adriamycin+streptozocin & 2 \\
Dacarbazine & 1 \\
Sunitinib & 5 \\
RAD001 & 3 \\
Total & 66
\end{tabular}

EP, etoposide and cisplatin; EC, etoposide carboplatin; CAV, cyclophosphamide, adriamycin and vincristine; TC, paclitaxel and carboplatin; TP, paclitaxel and cisplatin; DP, docetaxel and cisplatin; DC, docetaxel and carboplatin; VIP, etoposide, ifosfamide and cisplatin; FOLFOX, 5-fluorouracil (5FU), leucovorin and oxaliplatin; XELOX, capecitabine, oxaliplatin; FP, 5-FU and cisplatin; FC, 5-FU and carboplatin; IP, irinotecan and cisplatin; RAD001, everolimus

NETs from all sites of body and we did not have sufficient number of Ki-67 data, we followed the analysis method used in the SEER report, which included NETs from most sites and classified NETs into 4 grade groups (Grade 1-4). We used it also to compare our results with SEER report.

Presence of liver metastasis was related to shorter TTP $(p=.011)$ and lower ORR $(p=.009)$ in our study. Presence of liver metastasis tended to be related to a worse response to chemotherapy. A relationship between liver metastasis of NET and response to chemotherapy has rarely been reported before. Further study is required to fully understand the implications of

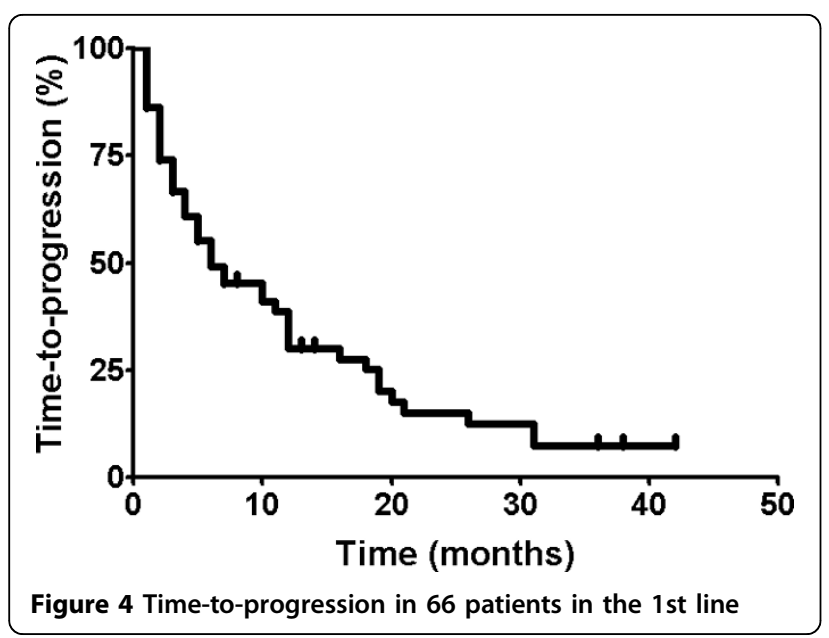

this result. In this case, it suggests a possible role for local treatment modalities in the treatment of NET patients with liver metastasis.

On the contrary, the presence of liver metastasis was not related to OS in our study. The presence of liver metastasis was reported as a negative prognostic factor among all stages of NET in some studies [14], while it has seldom been studied as a prognostic factor among metastatic NETs as in our study.

Urinary 5-HIAA [15] and serum NSE [9] have been well known as a prognostic factor. Patients whose serum NSE level was elevated showed a shorter OS in our study although statistically insignificant $(p=.051)$. And elevation of serum NSE $(p=.034)$ was related to a higher ORR. More research should be done to further explore this relationship between serum NSE and response to chemotherapy.

In metastatic disease, pancreatic NET has been generally known to have a poor prognosis compared to GI NET [16]. Pancreatic NET has been known to be more chemosensitive than GI NET [3,17]. Comparison of survival and treatment outcome between pancreatic, GI and lung NET in a metastatic setting has rarely been done yet. Treatment outcome after systemic treatment was not statistically different according to the origins of the primary tumor found in the pancreas, GI tract, or lungs in this study.

Patients received either local treatment modalities or systemic treatment modalities or both. Local treatment modalities such as TACE, metastasectomy, endoscopic removal, and radiotherapy were given actively in the course of treatment. Whatever treatment modalities patients received did not influence patients' survival in our study. However, tendency to survive the longest was observed in patients who received local treatment only, followed by patients who received both treatments. In a subgroup analysis within the 3 groups, the systemic treatment group was related to high grade $(p=.037)$ and extrahepatic metastasis $(p=.015)$ (Table 7).

Recently in a large retrospective study, the role of surgery was demonstrated in distant pancreatic NET [18]. However, there have been few studies which compared local with systemic treatment modalities or systemic with both treatment modalities in a randomized controlled setting [19].

Regimens used in systemic treatment were diverse in this study. Eleven patients received biotherapy such as IFN and somatostatin analogues as the 1st-line. However, which kind of biotherapy or chemotherapy they received did not have any relationship to treatment outcome and survival in our study.

IFN $-\alpha$ has been used for treatment of patients with NETs for more than 20 years $[20,21]$. However, its antitumor efficacy has not been satisfactory $[22,23]$. 
Table 5 Overall survival and time-to-progression $(n=66)$

\begin{tabular}{|c|c|c|c|c|c|c|c|c|c|c|}
\hline Characteristic & & & $\begin{array}{c}\text { OS* } \\
\text { (months) }\end{array}$ & $\begin{array}{c}95 \% \\
\mathrm{Cl}\end{array}$ & $\begin{array}{l}\text { 1-year survival } \\
\text { rate }(\%)\end{array}$ & $\begin{array}{c}P- \\
\text { value }\end{array}$ & $\begin{array}{c}\text { TTP } \\
\text { (months) }\end{array}$ & $\begin{array}{c}95 \% \\
\mathrm{Cl}\end{array}$ & $\begin{array}{l}\text { 1-year survival } \\
\text { rate }(\%)\end{array}$ & $\begin{array}{c}P- \\
\text { value }\end{array}$ \\
\hline Age & $\begin{array}{l}<60 \\
\geq 60\end{array}$ & & $\begin{array}{l}26.0 \\
25.0\end{array}$ & $\begin{array}{c}18.9- \\
33.1 \\
14.2- \\
35.8\end{array}$ & $\begin{array}{l}69.2 \\
69.9\end{array}$ & .656 & $\begin{array}{l}6.0 \\
6.0\end{array}$ & $\begin{array}{c}2.8- \\
9.2 \\
0.8- \\
11.2\end{array}$ & $\begin{array}{l}26.9 \\
35.4\end{array}$ & .611 \\
\hline Sex & $\begin{array}{l}\text { Male } \\
\text { Female }\end{array}$ & & $\begin{array}{l}22.0 \\
27.0\end{array}$ & $\begin{array}{c}15.9- \\
28.1 \\
19.3- \\
34.7\end{array}$ & $\begin{array}{l}69.1 \\
69.6\end{array}$ & .134 & $\begin{array}{l}6.0 \\
6.0\end{array}$ & $\begin{array}{c}0.0- \\
14.2 \\
\\
2.7- \\
9.3\end{array}$ & $\begin{array}{l}28.0 \\
34.6\end{array}$ & .771 \\
\hline Pancreas & & 28.0 & $18.0-38.0$ & 77.1 & .981 & 7.0 & $0.0-15.0$ & 41.6 & & \\
\hline Origin & $\mathrm{Gl}$ & & 22.0 & $\begin{array}{l}0.0- \\
46.9\end{array}$ & 63.2 & & 2.0 & $\begin{array}{l}0.8- \\
3.2\end{array}$ & 25.0 & .258 \\
\hline & Lung & & 9.0 & - & 50.0 & & 1.0 & - & - & \\
\hline $\begin{array}{l}\text { Liver } \\
\text { metastasis }\end{array}$ & $\begin{array}{l}\text { Absent } \\
\text { Present }\end{array}$ & & $\begin{array}{l}25.0 \\
22.0\end{array}$ & $\begin{array}{c}20.8- \\
29.2 \\
\\
13.3- \\
30.7\end{array}$ & $\begin{array}{l}77.0 \\
65.0\end{array}$ & .310 & $\begin{array}{l}12.0 \\
4.0\end{array}$ & $\begin{array}{c}9.2- \\
14.8 \\
\\
1.3- \\
6.7\end{array}$ & $\begin{array}{l}40.7 \\
23.8\end{array}$ & .011 \\
\hline & $\begin{array}{l}1 \\
2-3\end{array}$ & & $\begin{array}{l}36.0 \\
17.0\end{array}$ & $\begin{array}{c}13.2- \\
58.8 \\
1.1- \\
32.9\end{array}$ & 72.4 & .612 & 12.0 & $\begin{array}{l}8.3- \\
15.7 \\
1.2- \\
6.8\end{array}$ & $\begin{array}{l}57.5 \\
34.3\end{array}$ & \\
\hline Grade & Large & & 12.0 & $\begin{array}{l}0.0- \\
29.8\end{array}$ & 50.0 & & 2.0 & $\begin{array}{l}0.0- \\
4.5\end{array}$ & 45.0 & .681 \\
\hline & Small & & 17.0 & $\begin{array}{l}10.1- \\
23.9\end{array}$ & 100.0 & & 12.0 & $\begin{array}{l}2.6- \\
21.4\end{array}$ & 30.0 & \\
\hline & $\begin{array}{l}\text { 24-hour urine 5-HIAA } \\
\text { ( } \mu \mathrm{mol} / \text { day })\end{array}$ & $<31.4$ & 20.0 & $\begin{array}{l}0.0- \\
52.2\end{array}$ & 60.0 & .114 & 1.0 & - & - & .045 \\
\hline & & $\begin{array}{l}\geq \\
31.4\end{array}$ & 40.0 & - & 62.5 & & 12.0 & $\begin{array}{l}0.0- \\
29.6\end{array}$ & 44.4 & \\
\hline
\end{tabular}

Biomarkers

\begin{tabular}{|c|c|c|c|c|c|c|c|c|c|c|}
\hline & Serum NSE (nmol/l) & $\begin{array}{l}<1.0 \\
\geq 1.0\end{array}$ & $\begin{array}{c}25.0 \\
6.0\end{array}$ & $\begin{array}{l}18.0- \\
32.0 \\
0.0- \\
18.0\end{array}$ & $\begin{array}{l}75.0 \\
46.4\end{array}$ & .170 & $\begin{array}{l}2.0 \\
4.0\end{array}$ & $\begin{array}{c}0.9- \\
3.1 \\
1.2- \\
6.8\end{array}$ & $\begin{array}{c}0.0 \\
22.2\end{array}$ & .381 \\
\hline \multirow{3}{*}{ Regimen } & IFN & & 36.0 & $\begin{array}{l}22.6- \\
49.4\end{array}$ & 86.7 & .169 & 10.0 & $\begin{array}{l}0.0- \\
25.6\end{array}$ & 22.9 & \multirow{3}{*}{.057} \\
\hline & Somatostatin-analogue ${ }^{\dagger}$ & & 3.0 & & 50.0 & & 0.0 & - & - & \\
\hline & Chemotherapy & & 20.0 & $\begin{array}{l}13.3- \\
26.7\end{array}$ & 64.5 & & 6.0 & $\begin{array}{l}3.6- \\
8.4\end{array}$ & 34.2 & \\
\hline $\begin{array}{l}\text { Treatment } \\
\text { modality }\end{array}$ & $\begin{array}{l}\text { Systemic treatment only } \\
\text { Systemic+local treatment }\end{array}$ & & $\begin{array}{l}23.0 \\
29.0\end{array}$ & $\begin{array}{c}0.4- \\
45.6 \\
\\
23.6- \\
34.4\end{array}$ & $\begin{array}{l}57.9 \\
86.1\end{array}$ & .350 & & & & \\
\hline
\end{tabular}

OS, overall survival; TTP, time-to-progression; $\mathrm{Cl}$, confidence interval; 5-HIAA, 5-hydroxyindoleacetic acid; NSE, neuron-specific enolase; IFN, interferon *OS was estimated after initiation of systemic treatment except in treatment modality where OS was calculated after diagnosis of metastasis.

${ }^{\dagger}$ Somatostatin-analogue was given to only 2 patients.

Somatostatin analogues have been considered mainly an antisecretory drug for symptom control in NET and its ability to control the growth of NET has been a matter of debate [22]. Recently, a result from a randomized controlled trial was reported which demonstrated favorable response and prolongation of TTP after use of somatostatin analogues in well-differentiated midgut NET [24]. 
Table 6 Overall response rate and disease-control rate $(n=66)$

\begin{tabular}{|c|c|c|c|c|c|c|}
\hline Characteristic & & & ORR (\%) & $P$-value & DCR (\%) & $P$-value \\
\hline Age & $\begin{array}{l}<60 \\
\geq 60\end{array}$ & & $\begin{array}{l}35.3 \\
31.6 \\
\end{array}$ & .784 & $\begin{array}{l}61.8 \\
68.4 \\
\end{array}$ & .628 \\
\hline Sex & $\begin{array}{l}\text { Male } \\
\text { Female }\end{array}$ & & $\begin{array}{l}30.3 \\
40.0\end{array}$ & .470 & $\begin{array}{l}69.7 \\
55.0\end{array}$ & .279 \\
\hline Origin & $\begin{array}{l}\text { Pancreas } \\
\text { Gl } \\
\text { Lung }\end{array}$ & & $\begin{array}{c}35.7 \\
30.8 \\
0.0\end{array}$ & 1.000 & $\begin{array}{c}71.4 \\
38.5 \\
0.0\end{array}$ & .055 \\
\hline Liver metastasis & $\begin{array}{l}\text { Absent } \\
\text { Present }\end{array}$ & & $\begin{array}{l}58.8 \\
22.2\end{array}$ & .009 & $\begin{array}{l}82.4 \\
55.6\end{array}$ & .072 \\
\hline Grade & $\begin{array}{l}1 \\
2-3 \\
\text { Large } \\
\text { Small }\end{array}$ & & $\begin{array}{l}33.3 \\
44.4 \\
40.0 \\
33.3 \\
\end{array}$ & .460 & $\begin{array}{c}66.7 \\
66.7 \\
\\
40.0 \\
100.0\end{array}$ & .433 \\
\hline & 24-hour urine 5-HIAA ( $\mu \mathrm{mol} /$ day) & $\begin{array}{l}<31.4 \\
\geq 31.4\end{array}$ & $\begin{array}{l}0.0 \\
33.3\end{array}$ & .455 & $\begin{array}{l}20.0 \\
66.7\end{array}$ & .242 \\
\hline Biomarkers & Serum NSE (nmol/l) & $\begin{array}{l}<1.0 \\
\geq 1.0\end{array}$ & $\begin{array}{l}0.0 \\
55.6\end{array}$ & .034 & $\begin{array}{l}28.6 \\
77.8\end{array}$ & .126 \\
\hline Regimen & $\begin{array}{l}\text { IFN } \\
\text { Somatostatin-analogue* } \\
\text { Chemotherapy }\end{array}$ & & $\begin{array}{c}23.1 \\
0.0 \\
39.5\end{array}$ & .400 & $\begin{array}{c}53.8 \\
0.0 \\
71.1\end{array}$ & .079 \\
\hline
\end{tabular}

ORR, overall response rate; DCR, disease-control rate; Gl, gastrointestinal; 5-HIAA, 5-hydroxyindoleacetic acid; NSE, neuron-specific enolase; IFN, interferon

*Somatostatin-analogue was given to only 2 patients.

The standard chemotherapy for pancreatic NET has been a combination of adriamycin and streptozotocin and to a lesser extent a combination of 5-fluorouracil (5-FU) and streptozotocin [3]. Although 5-FU and streptozotocin have shown modest antitumor effect, there has been no clear standard chemotherapy for carcinoid

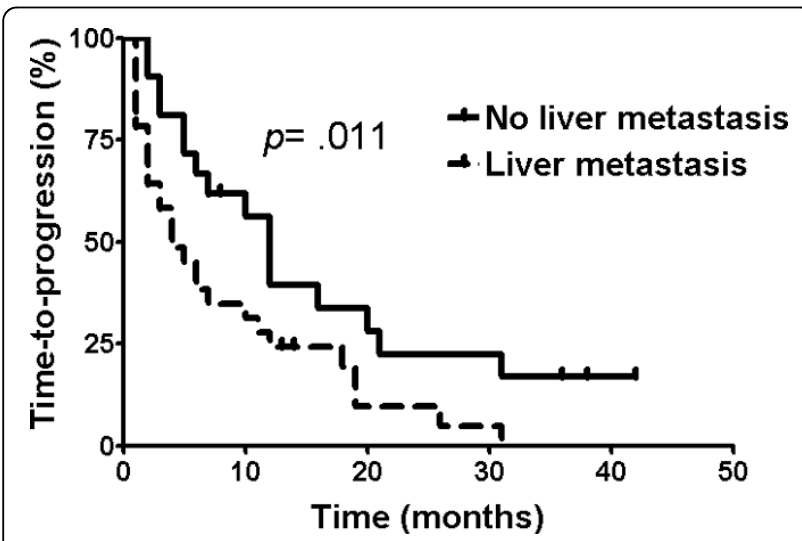

Figure 5 Time-to-progression according to presence of liver metastasis tumors $[23,25]$. Some reports have suggested a higher chemosensitivity of undifferentiated or poorly differentiated NET with etoposide-cisplatin combination $[2,26]$.

Recently, several new agents including target agents are actively being tried for advanced NET. Sunitinib showed $16.7 \%$ of ORR and $68 \%$ of DCR in pancreatic NETs in a nonrandomized study [27]. In a phase II trial, everolimus (RAD001) and octreotide long-acting repeatable (LAR) showed $22 \%$ of ORR and $70 \%$ of DCR in advanced low to intermediate-grade NETs [7]. Besides these drugs, cytotoxic chemotherapy including a capecitabine-oxaliplatin combination [11] also showed modest antitumor activities in advanced NETs. Radiolabeled somatostatin analogues have been tried actively and showed modest antitumor activities [28,29].

In our analysis, there are several limitations. This was a retrospective study so information such as carcinoid syndrome and biochemical features was not available in all of the patients. And the data pool was heterogeneous and the used regimens were diverse, even though the relative rarity of NETs makes it difficult to collect sufficient numbers of homogenous groups. 
Table 7 Comparison according to treatment modality $(n=63)$

\begin{tabular}{|c|c|c|c|c|c|}
\hline & & $\begin{array}{c}\text { Local } \\
\text { treatment }\end{array}$ & $\begin{array}{c}\text { Systemic } \\
\text { treatment }\end{array}$ & $\begin{array}{c}\text { Both } \\
\text { treatments }\end{array}$ & $P$-value \\
\hline \multirow{2}{*}{ Grade } & $\begin{array}{l}1 \\
2-3\end{array}$ & $\begin{array}{c}14(73.7 \%) \\
3(15.8 \%)\end{array}$ & $\begin{array}{l}7(38.9 \%) \\
8(44.4 \%)\end{array}$ & $\begin{array}{c}13(50.0 \%) \\
3(11.5 \%)\end{array}$ & \multirow{2}{*}{.037} \\
\hline & $\begin{array}{l}\text { Large } \\
\text { Small }\end{array}$ & $\begin{array}{l}1(5.3 \%) \\
1(5.3 \%)\end{array}$ & $\begin{array}{l}3(16.7 \%) \\
0(0.0 \%)\end{array}$ & $\begin{array}{l}5(19.2 \%) \\
5(19.2 \%)\end{array}$ & \\
\hline Metastatic site & $\begin{array}{l}\text { Extrahepatic metastasis } \\
\text { Liver metastasis only }\end{array}$ & $\begin{array}{l}7(33.3 \%) \\
14(66.7 \%)\end{array}$ & $\begin{array}{l}17(77.3 \%) \\
5(22.7 \%)\end{array}$ & $\begin{array}{l}11(52.4 \%) \\
10(47.6 \%)\end{array}$ & .015 \\
\hline
\end{tabular}

Other limitation is that we did not analyze the prognosis and response to systemic treatment according to the Ki67 status of tumors. The Ki67 is being regarded as an important prognostic factor which demonstrates the proliferative capacity of tumors [30]. In our patient pool, there was no available full data on Ki67. Furthermore, we did not have data about serum chromogranin A, of which the clinical meaning and importance are being highlighted nowadays, because this study was a retrospective research composed of patients from 1996. Further study on NET should harbor the contents of Ki67 and chromogranin A.

Nevertheless, this study has several strong points. There have been few reports which dealt with metastatic/recurrent NET as a whole group and showed the treatment outcomes. And we tried to search for predictive factors after palliative systemic treatment. Furthermore, we described the treatment patterns and outcomes in terms of continuum of care. And, as far as we know, this is one of the largest studies which have been done to date with this disease group in Asian countries.

\section{Conclusions}

OS of metastatic/recurrent NET was different according to tumor grade and TTP was different according to metastasis site. Therefore, development of optimal treatment strategy based on the characteristics of NET as well as new active agents is warranted.

\section{Acknowledgements}

The authors have nothing to acknowledge.

\section{Author details}

${ }^{1}$ Department of Internal Medicine, Seoul National University Hospital, Seoul National University College of Medicine, Seoul, Republic of Korea. ${ }^{2}$ Cancer Research Institute, Seoul National University College of Medicine, Seoul, Republic of Korea.

\section{Authors' contributions}

SJK and JWK were involved in collecting and analyzing data and drafting the manuscript. DYO and YJB conceived of the study and participated in its design and coordination. SHJ, DWK, SAI, TYK, and DSH helped to collect the patient pools. DYO and all the other authors read and approved the final manuscript.

\section{Competing interests}

The authors declare that they have no competing interests.

Received: 9 December 2009 Accepted: 23 August 2010

Published: 23 August 2010

\section{References}

1. Ransom WB: A case of primary carcinoma of the ileum. Lancet 1890 2:1020-1023.

2. Moertel CG, Kvols LK, O'Connell MJ, Rubin J: Treatment of neuroendocrine carcinomas with combined etoposide and cisplatin. Evidence of major therapeutic activity in the anaplastic variants of these neoplasms. Cancer 1991, 68(2):227-232.

3. Moertel CG, Hanley JA, Johnson LA: Streptozocin alone compared with streptozocin plus fluorouracil in the treatment of advanced islet-cell carcinoma. N Engl J Med 1980, 303(21):1189-1194.

4. Moertel CG, Lefkopoulo M, Lipsitz S, Hahn RG, Klaassen D: Streptozocindoxorubicin, streptozocin-fluorouracil or chlorozotocin in the treatment of advanced islet-cell carcinoma. N Engl J Med 1992, 326(8):519-523.

5. Yao JC, Hassan M, Phan A, Dagohoy C, Leary C, Mares JE, Abdalla EK, Fleming JB, Vauthey JN, Rashid A, et al: One hundred years after "carcinoid": epidemiology of and prognostic factors for neuroendocrine tumors in 35,825 cases in the United States. J Clin Oncol 2008, 26(18):3063-3072.

6. Ekeblad S, Sundin A, Janson ET, Welin S, Granberg D, Kindmark H, Dunder K, Kozlovacki G, Orlefors H, Sigurd M, et al: Temozolomide as monotherapy is effective in treatment of advanced malignant neuroendocrine tumors. Clin Cancer Res 2007, 13(10):2986-2991.

7. Yao JC, Phan AT, Chang DZ, Wolff RA, Hess K, Gupta S, Jacobs C, Mares JE, Landgraf AN, Rashid A, et al: Efficacy of RAD001 (everolimus) and octreotide LAR in advanced low- to intermediate-grade neuroendocrine tumors: results of a phase II study. J Clin Oncol 2008, 26(26):4311-4318.

8. Cho CS, Labow DM, Tang L, Klimstra DS, Loeffler AG, Leverson GE, Fong Y, Jarnagin WR, D'Angelica MI, Weber SM, et al: Histologic grade is correlated with outcome after resection of hepatic neuroendocrine neoplasms. Cancer 2008, 113(1):126-134.

9. Bettini R, Boninsegna L, Mantovani W, Capelli P, Bassi C, Pederzoli P, Delle Fave GF, Panzuto F, Scarpa A, Falconi M: Prognostic factors at diagnosis and value of WHO classification in a mono-institutional series of 180 non-functioning pancreatic endocrine tumours. Ann Oncol 2008, 19(5):903-908

10. Kaltsas G, Mukherjee JJ, Plowman PN, Grossman AB: The role of chemotherapy in the nonsurgical management of malignant neuroendocrine tumours. Clin Endocrinol (Oxf) 2001, 55(5):575-587.

11. Bajetta E, Catena L, Procopio G, De Dosso S, Bichisao E, Ferrari L, Martinetti A, Platania M, Verzoni E, Formisano B, et al: Are capecitabine and oxaliplatin (XELOX) suitable treatments for progressing low-grade and high-grade neuroendocrine tumours? Cancer Chemother Pharmacol 2007 59(5):637-642.

12. Hainsworth JD, Spigel DR, Litchy S, Greco FA: Phase II trial of paclitaxel, carboplatin, and etoposide in advanced poorly differentiated neuroendocrine carcinoma: a Minnie Pearl Cancer Research Network Study. J Clin Oncol 2006, 24(22):3548-3554.

13. Igawa $S$, Watanabe $R$, Ito I, Murakami H, Takahashi T, Nakamura $Y$, Tsuya A, Kaira K, Naito T, Endo M, et al: Comparison of chemotherapy for 
unresectable pulmonary high-grade non-small cell neuroendocrine carcinoma and small-cell lung cancer. Lung Cancer 2009, 68(3):438-45.

14. Tomassetti P, Campana D, Piscitelli L, Casadei R, Santini D, Nori F, MorselliLabate AM, Pezzilli R, Corinaldesi R: Endocrine pancreatic tumors: factors correlated with survival. Ann Oncol 2005, 16(11):1806-1810.

15. Rorstad O: Prognostic indicators for carcinoid neuroendocrine tumors of the gastrointestinal tract. J Surg Oncol 2005, 89(3):151-160.

16. Johanson V, Tisell LE, Olbe L, Wangberg B, Nilsson O, Ahlman H: Comparison of survival between malignant neuroendocrine tumours of midgut and pancreatic origin. Br J Cancer 1999, 80(8):1259-1261.

17. Ridolfi R, Amaducci L, Derni S, Fabbri L, Innocenti MP, Vignutelli P: Chemotherapy with 5-fluorouracil and streptozotocin in carcinoid tumors of gastrointestinal origin: experiences with 13 patients. $J$ Chemother 1991, 3(5):328-331.

18. Hill JS, McPhee JT, McDade TP, Zhou Z, Sullivan ME, Whalen GF, Tseng JF: Pancreatic neuroendocrine tumors: the impact of surgical resection on survival. Cancer 2009, 115(4):741-751.

19. Gurusamy KS, Ramamoorthy R, Sharma D, Davidson BR: Liver resection versus other treatments for neuroendocrine tumours in patients with resectable liver metastases. Cochrane Database Syst Rev 2009, , 2: CD007060.

20. Oberg K, Funa K, Alm G: Effects of leukocyte interferon on clinical symptoms and hormone levels in patients with mid-gut carcinoid tumors and carcinoid syndrome. N Engl J Med 1983, 309(3):129-133.

21. Pavel ME, Baum U, Hahn EG, Schuppan D, Lohmann T: Efficacy and tolerability of pegylated IFN-alpha in patients with neuroendocrine gastroenteropancreatic carcinomas. J Interferon Cytokine Res 2006, 26(1):8-13.

22. Faiss S, Pape UF, Bohmig M, Dorffel Y, Mansmann U, Golder W, Riecken EO, Wiedenmann B: Prospective, randomized, multicenter trial on the antiproliferative effect of lanreotide, interferon alfa, and their combination for therapy of metastatic neuroendocrine gastroenteropancreatic tumors-the International Lanreotide and Interferon Alfa Study Group. J Clin Oncol 2003, 21(14):2689-2696.

23. Dahan L, Bonnetain F, Rougier P, Raoul JL, Gamelin E, Etienne PL, Cadiot G, Mitry E, Smith D, Cvitkovic F, et al: Phase III trial of chemotherapy using 5fluorouracil (5-FU) and streptozotocin (STZ) compared with alpha interferon (IFN) for advanced carcinoid tumors: FNCLCC-FFCD 9710. Endocr Relat Cancer 2009

24. Rinke A, Muller HH, Schade-Brittinger C, Klose KJ, Barth P, Wied M, Mayer C, Aminossadati B, Pape UF, Blaker M, et al: Placebo-Controlled, Double-Blind, Prospective, Randomized Study on the Effect of Octreotide LAR in the Control of Tumor Growth in Patients With Metastatic Neuroendocrine Midgut Tumors: A Report From the PROMID Study Group. J Clin Oncol 2009.

25. Wirth LJ, Carter MR, Janne PA, Johnson BE: Outcome of patients with pulmonary carcinoid tumors receiving chemotherapy or chemoradiotherapy. Lung Cancer 2004, 44(2):213-220.

26. Fjallskog ML, Granberg DP, Welin SL, Eriksson C, Oberg KE, Janson ET, Eriksson BK: Treatment with cisplatin and etoposide in patients with neuroendocrine tumors. Cancer 2001, 92(5):1101-1107.

27. Kulke MH, Lenz HJ, Meropol NJ, Posey J, Ryan DP, Picus J, Bergsland E, Stuart $K$, Tye L, Huang $X$, et al: Activity of sunitinib in patients with advanced neuroendocrine tumors. J Clin Oncol 2008, 26(20):3403-3410.

28. Virgolini I, Britton K, Buscombe J, Moncayo R, Paganelli G, Riva P: In- and YDOTA-lanreotide: results and implications of the MAURITIUS trial. Semin Nucl Med 2002, 32(2):148-155.

29. Kwekkeboom DJ, de Herder WW, Kam BL, van Eijck CH, van Essen M, Kooij PP, Feelders RA, van Aken MO, Krenning EP: Treatment with the radiolabeled somatostatin analog [177 Lu-DOTA 0,Tyr3]octreotate: toxicity, efficacy, and survival. J Clin Oncol 2008, 26(13):2124-2130.

30. Vilar E, Salazar R, Perez-Garcia J, Cortes J, Oberg K, Tabernero J: Chemotherapy and role of the proliferation marker Ki-67 in digestive neuroendocrine tumors. Endocr Relat Cancer 2007, 14(2):221-232.

\section{Pre-publication history}

The pre-publication history for this paper can be accessed here:

http://www.biomedcentral.com/1471-2407/10/448/prepub doi:10.1186/1471-2407-10-448

Cite this article as: Kim et al: Biological characteristics and treatment outcomes of metastatic or recurrent neuroendocrine tumors: tumor grade and metastatic site are important for treatment strategy. $B M C$ Cancer 2010 10:448.

\section{Submit your next manuscript to BioMed Central and take full advantage of:}

- Convenient online submission

- Thorough peer review

- No space constraints or color figure charges

- Immediate publication on acceptance

- Inclusion in PubMed, CAS, Scopus and Google Scholar

- Research which is freely available for redistribution

Submit your manuscript at www.biomedcentral.com/submit
Ciomed Central 